\title{
PENINGKATAN KUALITAS PEMBELAJARAN MATEMATIKA MELALUI PENERAPAN METODE TUTOR SEBAYA PADA MURID KELAS IV SDN TOPA BAUBAU
}

\author{
IRSAN* \\ Program Studi Pendidikan Guru Sekolah Dasar, Fakultas Keguruan dan Ilmu Pendidikan \\ Universitas Muhammadiyah Buton, Jl. Betoambari No. 36, Lanto, Batupoaro, \\ Kota BauBau, Sulawesi Tenggar, Indonesia 93717
}

\begin{abstract}
Improving the Quality of Mathematics Learning through the Application of Peer Tutor Method on Student IV of SDN Topa Baubau. Irsan. Primary teacher education. Faculty of Teacher Training and Education. University of Muhammadiyah Buton.

This research is a classroom action research that aims to improve the quality of Mathematics learning through the application of Peer Tutor method to fourth grade students of SDN Topa Baubau in the even semester of academic year 2017/2018 with a total of 30 students. This research was conducted in two cycles. Each cycle has several stages: planning, execution, observation / observation, and reflection. Each cycle is held in 4 meetings. Data retrieval is done by using learning result test and observation. The collected learning result data was analyzed by using quantitative analysis and observation data was analyzed qualitatively. The results showed that the average score of students in the first cycle was 60.66, while in cycle II obtained an average score of 78. KKM standard used in schools is 65, it indicates that has been achieved student learning outcomes in class. From the results of this study can be concluded that by applying the Tutor Sebaya method of learning quality of Mathematics in fourth grade students of SDN Topa Baubau can increase.
\end{abstract}

Keywords: Peer Tutor Method. Quality of Mathematics Learning. 


\begin{abstract}
ABSTRAK
Peningkatan Kualitas Pembelajaran Matematika melalui Penerapan Metode Tutor Sebaya pada Murid Kelas IV SDN Topa Baubau. Irsan. Pendidikan Guru Sekolah Dasar. Fakultas Keguruan dan Ilmu Pendidikan. Universitas Muhammadiyah Buton.

Penelitian ini adalah penelitian tindakan kelas (classroom action research) yang bertujuan untuk meningkatkan kualitas pembelajaran Matematika melalui penerapan metode Tutor Sebaya pada murid kelas IV SDN Topa Baubau semester genap tahun ajaran 2017/2018 dengan jumlah murid 30 orang. Penelitian ini dilaksanakan sebanyak dua siklus. Tiap siklus memiliki beberapa tahapan yaitu perencanaaan, pelaksanaan, pengamatan/observasi, dan refleksi. Masing-masing di siklus dilaksanakan 4 kali pertemuan. Pengambilan data dilakukan dengan menggunakan tes hasil belajar dan observasi. Data hasil belajar yang terkumpul dianalisis dengan menggunakan analisis kuantitatif dan data hasil observasi dianalisis secara kualitatif. Hasil penelitian menunjukkan bahwa skor rata-rata murid pada siklus I adalah 60,66, sedangkan pada siklus II diperoleh skor rata-rata 78. Standar KKM yang digunakan di sekolah adalah 65, hal ini menunjukkan bahwa telah tercapai hasil belajar murid secara klasikal. Dari hasil penelitian ini dapat disimpulkan bahwa dengan menerapkan metode Tutor Sebaya kualitas pembelajaran Matematika pada murid kelas IV SDN Topa Baubau dapat meningkat.

Kata kunci: Metode Tutor Sebaya. Kualitas Pembelajaran Matematika.
\end{abstract}




\section{PENDAHULUAN}

Berbagai upaya telah dilakukan untuk meningkatkan mutu pendidikan di sekolah, antara lain dengan perbaikan mutu pembelajaran. Pembelajaran di sekolah merupakan serangkaian kegiatan yang secara sadar telah terencana. Dengan adanya perencanaan yang baik akan mendukung keberhasilan pengajaran. Usaha perencanaan pengajaran diupayakan agar peserta didik memiliki kemampuan maksimal dan meningkatkan motivasi, tantangan dan kepuasan sehingga mampu memenuhi harapan baik oleh guru sebagai pembawa materi maupun peserta didik sebagai penggarap ilmu pengetahuan.

Keberhasilan program pendidikan melalui pembelajaran di sekolah sebagai lembaga pendidikan formal sangat dipengaruhi oleh beberapa faktor yaitu murid, kurikulum, tenaga kependidikan, biaya, sarana dan prasarana serta faktor lingkungan. Apabila faktor-faktor tersebut dapat terpenuhi sudah tentu akan memperlancar proses pembelajaran, yang akan menunjang pencapaian hasil belajar yang maksimal yang pada akhirnya akan meningkatkan mutu pendidikan.

Pendidikan formal merupakan wujud nyata upaya pembinaan sumber daya manusia Indonesia yang berkualitas sebagai bukti kepedulian pemerintah. Dalam upaya pengembangan sumber daya manusia yang berkualitas, maka juga diperlukan kemampuan berfikir dan sikap kemandirian murid selaku peserta didik. Oleh sebab itu menjadi prasyarat bagi proses pendidikan untuk manusia Indonesia yang mampu menghadapi dan mengantisipasi tantangan pembangunann di masa yang akan datang.

Matematika sebagai salah satu sarana berpikir ilmiah sangat diperlukan untuk menumbuhkembangkan kemampuan berpikir logis, sistematis, kritis, kreatif, dan kemampuan bekerja sama. Cara berpikir seperti ini dapat dikembangkan melalui belajar matematika, karena matematika memiliki struktur dan keterkaitan yang kuat dan jelas antar konsepnya sehingga memungkinkan murid terampil berpikir rasional. Kita menyadari bahwa pelajaran Matematika cenderung dipandang sebagai pelajaran yang kurang diminati murid. Seharusnya murid menyadari bahwa aturan-aturan yang ada dalam Matematika mengajarkan untuk dapat berpikir secara logis, rasional, kritis, cermat, efisien, dan efektif. Kemampuan tersebut sangat dibutuhkan untuk 
menyongsong era persaingan bebas. Kreatifitas seorang guru dalam mengajar matematika menjadi faktor penting agar matematika menjadi mata pelajaran yang menyenangkan dan menarik di dalam kelas. Kreatifitas bukanlah suatu bakat tetapi bisa dipelajari dan harus dilatih.

Berdasarkan observasi yang dilakukan pada murid kelas IV SDN Topa Baubau rata-rata ujian Matematika murid kelas IV semester ganjil Tahun Ajaran 2017/2018 yaitu 60, dimana nilai rata-rata murid dalam pelajaran Matematika lebih rendah dari standar Kriteria Ketuntasan Minimal (KKM) yaitu 65. Untuk itu diperlukan solusi agar seluruh murid merasa menjadi bagian dalam proses belajar mengajar.

SDN Topa merupakan salah satu SD yang terdapat di Kecamatan Betoambari Kota Baubau yang saat ini perlu diadakan penelitian lebih lanjut karena dari observasi awal yang dilakukan peneliti pada tanggal 11 April 2018, secara umum menunjukkan bahwa aktivitas murid sangat rendah. Misalnya, kurangnya kemampuan murid dalam mengajukan dan menjawab pertanyaan, respon terhadap pembelajaran yang sangat minim, munculnya sikap acuh tak acuh murid dalam kelas, bahkan dalam beberapa kasus ditemukan adanya tenaga pengajar yang terkadang kewalahan untuk mengontrol murid dalam kelas. Pelaksanaan pembelajaran Matematika di SDN Topa, belum berlangsung sesuai harapan. Menurut informasi yang diperoleh oleh guru wali kelas IV SDN Topa, beliau mengatakan bahwa kemampuan muridnya dalam menyelesaikan soal-soal Matematika sangat rendah. Hal ini mungkin dikarenakan penyajian materi Matematika hanya menggunakan satu model pembelajaran saja yaitu model pembelajaran langsung.

Rendahnya hasil belajar Matematika murid disebabkan oleh beberapa faktor, diantaranya rendahnya keaktifan murid dalam belajar Matematika, kurang memperhatikan pengerjaan tugas-tugas, keterlibatan murid secara langsung dalam proses pembelajaran, dimana murid hanya sebagai pendengar dan pencatat dari apa yang disampaikan guru, dan didiktekan oleh guru kelas sehingga murid hanya menghafalkan konsep dan fakta tanpa mengetahui apa, bagaimana, untuk apa konsep dan fakta itu dipelajari. 
Menurut Hisyam Zaini dalam Amin Suyitno (2004:24) menyatakan bahwa "Metode belajar yang paling baik adalah dengan mengajarkan kepada orang lain". Oleh karena itu, pemilihan metode Tutor Sebaya sebagai strategi pembelajaran akan sangat membantu murid di dalam mengajarkan materi kepada teman-temannya. Metode ini dilakukan dengan cara memberdayakan kemampuan murid yang memiliki daya serap yang tinggi, murid tersebut mengajarkan materi/latihan kepada teman-temannya yang belum paham. Metode ini banyak sekali manfaatnya baik dari sisi murid yang berperan sebagai tutor maupun sebagai murid yang diajarkan. Peran guru adalah mengawasi kelancaran pelaksanaan metode ini dengan memberi pengarahan dan motivasi belajar. Melalui metode ini, diharapkan dapat meningkatkan hasil belajar Matematika murid kelas IV SDN Topa Baubau.

Uraian di atas memberikan penegasan pentingnya pemilihan dan penggunaan metode pembelajaran secara tepat agar dapat mendukung terciptanya proses pembelajaran yang berkualitas dan meningkatkan hasil belajar murid. Salah satu strategi pembelajaran yang dapat diterapkan dalam upaya meningkatkan hasil belajar murid adalah metode belajar Tutor Sebaya. Tutor Sebaya dikenal dengan pembelajaran teman sebaya atau antar peserta didik, hal ini bisa terjadi ketika peserta didik yang lebih mampu menyelesaiakan pekerjaannya sendiri dan kemudian membantu peserta didik lain yang kurang mampu. Adapun tujuan penelitian ini adalah untuk meningkatkan kualitas pembelajaran matematika melalui penerapan metode tutor sebaya pada kelas IV SDN Topa Baubau.

\section{METODE PENELITIAN}

Penelitian ini merupakan penelitian tindakan kelas (classroom action research). Pelaksanaan penelitian tindakan ini berbentuk siklus yang meliputi: perencanaan, pelaksanaan tindakan, observasi dan refleksi. Penelitian kelas ini dilaksanakan dengan dua siklus, dengan penerapan metode Tutor Sebaya. Adapun faktor yang diselidiki dalam penelitian ini yaitu : 
1) Faktor proses, yakni proses pelaksanaan pembelajaran matematika melalui metode tutor sebaya, dan aktivitas belajar murid dalam mengikuti pelajaran di kelas IV SDN Topa Baubau.

2) Faktor hasil belajar, yakni nilai hasil tes pelajaran matematika yang diberikan pada setiap akhir siklus.

Penelitian tindakan kelas ini dilaksanakan pada semester ganjil tahun ajaran 2014/2015 yang terbagi atas dua siklus. Setiap siklus dilaksanakan dengan empat kali pertemuan. Tiap siklus tersebut dilaksanakan sesuai dengan perubahan yang ingin dicapai, seperti yang telah didesain dalam faktor yang diselidiki.

Adapun rincian kegiatan yang akan dilakukan pada setiap siklus adalah sebagai berikut :

1. SIKLUS I

a. Tahap Perencanaan

1) Menelaah materi pelajaran Matematika murid kelas IV SDN Topa Baubau semester genap.

2) Membuat rencana pembelajaran.

3) Membuat soal-soal yang akan diberikan pada akhir siklus.

4) Membuat alat bantu mengajar seperti Lembar Kerja Siswa (LKS) yang diperlukan untuk mengoptimalisasi pembelajaran dengan metode Tutor Sebaya.

5) Membuat lembar observasi untuk melihat bagaimana kondisi murid pada saat proses belajar mengajar di kelas berlangsung yang meliputi kehadiran, keaktifan mengikuti pelajaran, rasa percaya diri dan keterampilan murid.

6) Membuat dan menyusun alat evaluasi untuk melihat kemampuan murid dalam menyelesaikan soal-soal berdasarkan materi yang diberikan.

b. Pelaksanaan Tindakan

Pada tahap ini dilaksanakan dengan perincian sebagai berikut :

1) Menyampaikan tujuan pembelajaran yang akan dicapai.

2) Murid membentuk kelompok kecil yang terdiri dari 4 atau 5 orang murid yang akan didampingi masing-masing tutor.

3) Guru menjelaskan dan mendemonstrasikan materi yang akan dipelajari. 
4) Guru (peneliti) menyampaikan permasalahan yang harus diselesaikan oleh murid.

5) Tiap kelompok menyelesaikan tugas yang diberikan oleh guru pada LKS didampingi tutor masing-masing kelompok.

6) Kelompok yang lain mebmberi tanggapan terhadap tugas kelompok lain.

7) Guru membimbing murid untuk membuat kesimpulan dari hasil kerja kelompok.

8) Merefleksi tindakan pembelajaran yang telah dilaksanakan.

c. Observasi

Pada tahap ini dilaksanakan proses observasi terhadap pelaksanaan tindakan dengan menggunakan lembar observasi.

Selama proses pembelajaran berlangsung akan diadakan pengamatan tentang :

1) Kesungguhan murid mengikuti kegiatan pembelajaran berupa perhatian murid dalam menyimak materi yang disajikan.

2) Rasa percaya diri yang diperlihatkan murid pada saat proses pembelajaran berlangsung.

3) Untuk mendapatkan informasi dari murid tentang kegiatan pembelajaran yang telah dilakukan maka murid diminta memberikan tanggapannya.

d. Refleksi

Hasil yang diperoleh dari tahap observasi dianalisis untuk melihat data observasi apakah kegiatan yang telah dilakukan dapat meningkatkan hasil belajar Matematika dengan menggunakan metode Tutor Sebaya.

Pada tahap ini dilihat sampai dimana faktor-faktor yang telah diselidiki telah dicapai. Hal-hal yang dipandang masih kurang akan dilanjutkan pada siklus kedua dengan suatu model tindakan yang lebih memperbaiki dengan mempertahankan apa yang sudah baik.

\section{SIKLUS II}

Pada siklus II ini akan dilaksanakan sebanyak empat kali pertemuan. Pada dasarnya langkah-langkah yang dilakukan pada siklus II telah memperoleh refleksi, selanjutnya dikembangkan dan dimodifikasi tahapan-tahapan yang ada pada siklus I 
dengan beberapa perbaikan dan penambahan sesuai dengan kenyataan yang ditemukan.

Data yang diperoleh akan dianalisis dengan menggunakan analisis statistik deskriptif yaitu skor rata-rata dan presentase, frekuensi, presentase nilai terendah dan nilai tertinggi yang dicapai murid setiap siklus, hasil observasi dan hasil respon murid.

Data hasil belajar yang diperoleh dikategorikan berdasarkan teknik kategorisasi standar yang ditetapkan oleh Departemen Pendidikan Nasional (Masriana $2010: 11$ )

\section{Tabel 1 Teknik Kategorisasi Standar Berdasarkan Ketetapan Depdiknas}

\begin{tabular}{|c|c|}
\hline Skor & Kategori \\
\hline $0-45$ & Sangat Rendah \\
$46-54$ & Rendah \\
$55-69$ & Sedang \\
$70-84$ & Tinggi \\
$85-100$ & Sangat Tinggi \\
\hline
\end{tabular}

Indikator keberhasilan pelaksanaan pembelajaran Matematika melalui metode Tutor Sebaya di kelas IV SDN Topa Baubau, yaitu apabila hasil belajar Matematika murid mengalami peningkatan dari siklus pertama ke siklus kedua, dan terjadi peningkatan aktivitas belajar murid dalam pembelajaran Matematika melalui metode Tutor Sebaya setiap pertemuan.

1. Ketuntasan individu dengan rumus:

$\mathrm{S}=\frac{R}{N}$

$\mathrm{S}=$ Presentase ketuntasan individual

$\mathrm{R}=$ Skor yang diperoleh

$\mathrm{N}=$ Skor maksimal

Murid dikatakan tuntas secara individual apabila murid tersebut mencapai nilai $65 \%$. 
2. Ketuntasan belajar klasikal dengan rumus :

$\mathrm{PK}=\frac{J T}{J S}$

PK = Presentase ketuntasan klasikal

JT = Jumlah murid yang tuntas

JS = Jumlah seluruh murid

Murid dikatakan tuntas secara klasikal apabila murid tersebut mencapai nilai $85 \%$.

\section{HASIL DAN PEMBAHASAN}

Berdasarkan hasil pengamatan murid pada siklus I dan siklus II yang dicatat dalam lembar observasi yang dilakukan selama proses pembelajaran diperoleh peningkatan aktivitas dan hasil belajar murid kelas IV SDN Topa Baubau.

a. Data perbandingan hasil observasi kegiatan murid kelas V SDN Topa Baubau pada siklus I dan siklus II setelah menerapkan metode Tutor Sebaya ada pada tabel 4.9 dibawah ini:

No.

Aspek yang diamati

Kesiapan murid dalam menerima

1. pelajaran dan menempati tempat

duduknya masing-masing

Mendengar dengan baik tujuan

2. pembelajaran yang ingin dicapai

Menyimak dengan serius saat

3.

materi pelajaran dijelaskan

Aktif bertanya saat proses

4.

pembelajaran berlangsung

5.

Murid terlibat aktif dalam proses

pembelajaran
Presentase (\%)

\section{Siklus I Siklus II}

$52,21 \quad 75,55$

$48,88 \quad 83,33$

$54,44 \quad 85,55$

$21,10 \quad 51,11$

$53,33 \quad 78,88$ 
6.

Murid yang aktif dalam

kelompoknya

Murid yang mampu menjawab

7. pertanyaan guru dengan baik dan benar

\section{$47,77 \quad 76,66$}

$49,99 \quad 73,33$

$327,67 \quad 524,41$

$46,81 \quad 74,91$

Tabel 2.Data Perbandingan Hasil Observasi Kegiatan Murid Kelas IV SDN Topa Baubau pada Siklus I dan II setelah Menerapkan Metode Tutor Sebaya

Grafik di bawah ini menunjukkan data perbandingan hasil observasi kegiatan murid kelas IV SDN Topa Baubau pada siklus I dan II setelah menerapkan metode Tutor Sebaya.

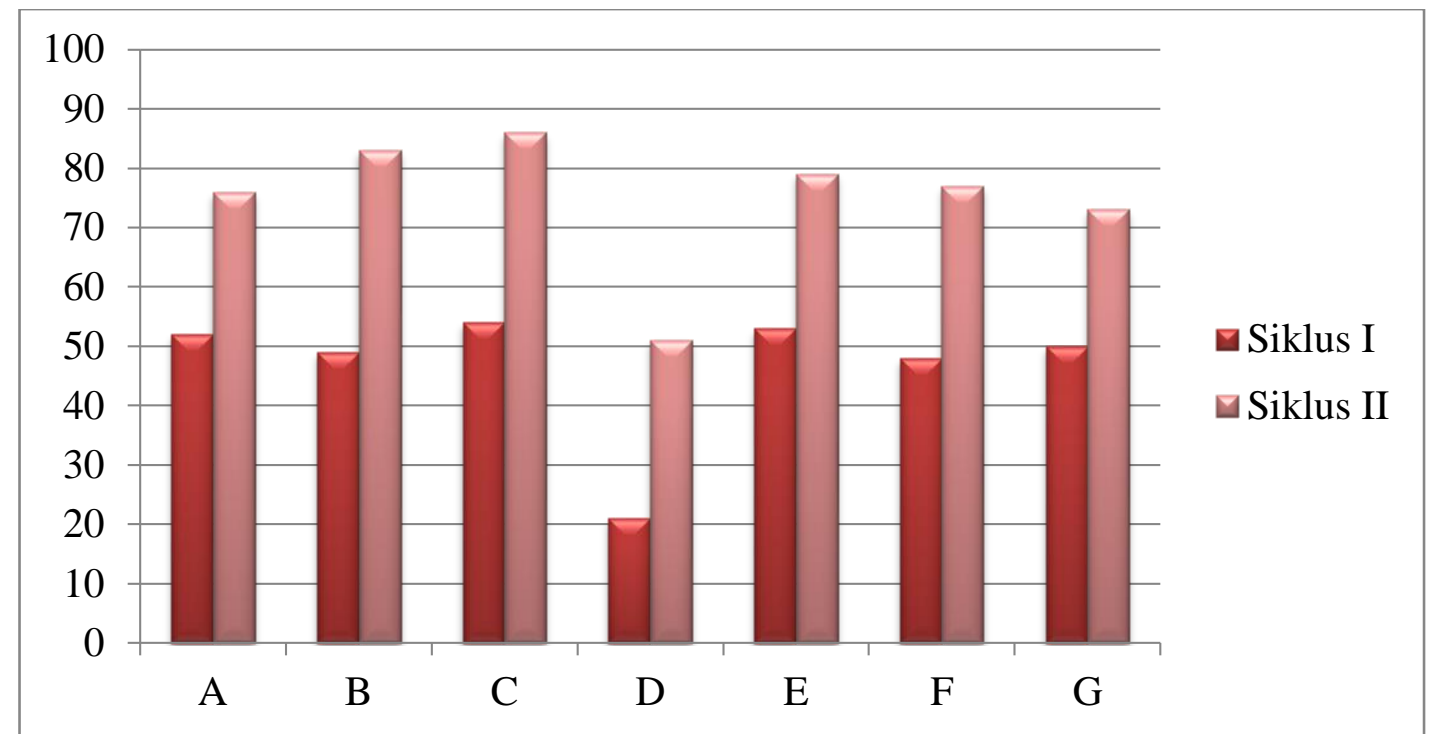

Grafik 1. Data Perbandingan Hasil Observasi Kegiatan Murid Kelas IV SDN Topa Baubau pada Siklus I dan II setelah Menerapkan Metode Tutor Sebaya

Penilaian terhadap hasil observasi kegiatan murid dari siklus I dan siklus II, antara lain: 
1) Kesiapan murid dalam menerima pelajaran dan menempati tempat duduknya masing-masing pada siklus I memperoleh nilai 52,21\%, sedangkan pada siklus II memperoleh nilai $75,55 \%$.

2) Murid yang mendengar dengan baik tujuan pembelajaran yang ingin dicapai pada siklus I memperoleh nilai 48,88\%, sedangkan pada siklus II memperoleh nilai $83,33 \%$.

3) Murid yang menyimak dengan serius saat materi pelajaran dijelaskan pada siklus I memperoleh nilai 54,44\%, sedangkan pada siklus II memperoleh nilai $85,55 \%$.

4) Murid yang aktif bertanya saat proses pembelajaran berlangsung pada siklus I memperoleh nilai $21,10 \%$, sedangkan pada siklus II memperoleh nilai $51,11 \%$.

5) Murid yang terlibat aktif dalam proses pembelajaran pada siklus I memperoleh nilai 53,33\%, sedangkan pada siklus II memperoleh nilai $78,88 \%$.

6) Murid yang aktif dalam kelompoknya, pada siklus I memperoleh nilai 47,77\%, sedangkan pada siklus II memperoleh nilai 76,66\%.

7) Murid yang mampu menjawab pertanyaan guru dengan baik dan benar pada siklus I memperoleh nilai 49,99\%, sedangkan pada siklus II memperoleh nilai $73,33 \%$.

Perbandingan hasil observasi kegiatan murid dapat dilihat pada hasil observasi kegiatan murid dari siklus I memperoleh rata-rata 46,81\% dan masuk dalam kategori rendah karena murid belum terbiasa dengan metode Tutor Sebaya yang diterapkan oleh peneliti sehingga murid masih banyak yang tidak serius dalam proses pembelajaran saat penelitian berlangsung. Hasil observasi kegiatan murid dari siklus II memperoleh rata-rata 74,91\% masuk dalam kategori tinggi karena murid sudah mulai mengenal metode Tutor Sebaya yang telah diterapkan oleh peneliti saat melakukan penelitian. 
b. Data perbandingan ketuntasan hasil belajar murid kelas IV SDN Topa Baubau pada siklus I dan siklus II setelah menerapkan metode Tutor Sebaya ada pada tabel 4.10 dibawah ini:

\begin{tabular}{|c|c|c|c|c|c|c|c|}
\hline \multirow[t]{3}{*}{ Siklus } & \multicolumn{3}{|c|}{ Skor Perolehan } & \multicolumn{2}{|c|}{ Tuntas } & \multicolumn{2}{|c|}{ Tidak Tuntas } \\
\hline & & Muri & & & & & \\
\hline & Min & Max & $\begin{array}{l}\text { Rata- } \\
\text { rata }\end{array}$ & Frekuensi & $\begin{array}{c}\text { Persentase } \\
\%\end{array}$ & Frekuensi & $\begin{array}{c}\text { Persentase } \\
\%\end{array}$ \\
\hline I & 20 & 90 & 60,66 & 13 & 56,66 & 17 & 43,34 \\
\hline II & 45 & 100 & 78 & 26 & 86,66 & 4 & 13,34 \\
\hline
\end{tabular}

\section{Tabel 3. Perbandingan Ketuntasan Hasil Belajar Siklus I dan Siklus II}

Dari tabel di atas, menunjukkan bahwa pada siklus I, persentase ketuntasan belajar murid sebesar 56,55\% yaitu 13 orang dari 30 murid dan presentase tidak tuntas belajar murid sebesar 43,34\% yaitu 17 dari 30 murid. Pada siklus II, presentase ketuntasan belajar murid sebesar 86,66\% yaitu 26 dari 30 murid, dan 13,34\% termasuk kategori tidak tuntas, yaitu 4 orang dari 30 murid.

Perbandingan ketuntasan hasil belajar murid dapat dilihat pada hasil belajar dari siklus I yang masih kurang karena peneliti belum menerapkan metode Tutor Sebaya secara optimal. Namun, pada siklus II hasil belajar murid dapat meningkat karena telah menerepkan metode Tutor Sebaya secara optimal.

\section{Hasil belajar Matematika murid kelas IV SDN Topa Baubau Setelah Menerapkan Metode Tutor Sebaya}

Pelaksanaan penelitian siklus I belum menunjukkan peningkatan hasil belajar Matematika murid kelas IV SDN SDN Topa Baubau setelah penerapan metode Tutor Sebaya, hal tersebut dapat dilihat dari nilai rata-rata evaluasi siklus I yang baru mencapai 60,66, sedangkan nilai rata-rata yang diharapkan minimal 65. Dari analisis daya serap murid juga belum mencapai indikator kebehasilan, ini dapat dilihat dari 30 murid kelas IV SDN Topa Baubau sebanyak 10\% yang penguasaan materinya masuk dalam kategori sangat rendah, 33,34\% masuk dalam kategori rendah, 20\% masuk 
dalam kategori sedang, 30\% masuk dalam kategori tinggi, dan 6,66\% masuk dalam kategori sangat tinggi setelah dilaksanakan tindakan siklus I.

Skor rata-rata hasil belajar Matematika murid pada siklus I adalah 60,66 dari skor ideal yang mungkin dicapai yaitu 100 berada pada interval 55 - 69. Dengan demikian, dapat disimpulkan bahwa belajar Matematika kelas IV SDN Topa Baubau masuk dalam kategori sedang.

Hasil evaluasi siklus II menunjukkan nilai rata-rata yang dicapai murid meningkat dari 60,66 (siklus I) menjadi 78 (siklus II) hasil belajar ini telah belajar telah tercapai sehingga tidak perlu lagi diadakan perbaikan pada siklus selanjutnya. Dengan demikian, terjadi peningkatan secara signifikan hasil belajar murid siklus I dan II, sehingga rata-rata murid memperoleh nilai hasil belajar masuk kategori tinggi. Evaluasi dilaksanakan untuk melihat hasil dan proses belajar murid yang dapat dilakukan dengan baik agar dapat mempengaruhi proses pembelajaran (Slameto, 2010: 53).

\section{KESIMPULAN}

Berdasarkan hasil penelitian tindakan kelas dan pembelajaran dalam penerapan metode Tutor Sebaya pada murid kelas IV SDN Topa Baubau menunjukkan bahwa hasil belajar Matematika dapat disimpulkan sebagai berikut:

1) Aktivitas belajar murid pada siklus I adalah 46,81\%, sedangkan siklus II 74,91\%. Ini menunjukkan bahwa terjadi peningkatan aktivitas belajar murid karena hampir semua murid aktif dalam kegiatan pembelajaran sehingga proses pembelajaran dapat berjalan secara optimal.

2) Nilai rata-rata yang diperoleh murid pada siklus I adalah 60,66 sedangkan siklus II adalah 78

3) Persentase ketuntasan belajar siklus I adalah 56,66\% menjadi 86,66\% pada siklus II.

\section{Ucapan Terima Kasih}

Ucapan terima kasih peneliti haturkan kepada seluruh teman dosen Program studi pendidikan guru sekolah dasar Fakultas keguruan dan ilmu pendidikan Universitas 
Muhammadiyah Buton yang telah memberikan dorongan dan semangat bagi penulis untuk melaksanakan penelitian ini. Ucapan terima kasih juga kepada Kepala Sekolah dan Guru Kelas di SDN Topa Baubau yang bersedia menerima dan membantu penulis dalam melaksanakan penelitian di sekolah tersebut.

\section{Daftar Pustaka}

Awan, Hendra, 2013. Upaya meningkatkan kualitas pembelajaran yang kreatif dan menyenangkan (m.authorsteam.com/presentation/hendraawan.1443949-upayameningkatkan-kualitas-pembelajaran-yang-kteatif-danmenyenangkana/,diakses 02 September 2014)

Suyitno, Amin. 2004. Tentang Tutor Sebaya. Yogyakarta : Graha Ilmu Pustaka KTI. $2012 . \quad$ Metode Tutor Sebaya. http://literaturkti.blogspot.com/2012/09/Metode-Tutor-Sebaya.html. Diakses 20 Januari 2015

Wawasan Pendidikan. 2014. Langkah-langkah Metode Tutor Sebaya dalam Kelompok. http://wawasanpendidikan.com/2014/09/langkah-langkah-metode-tutorsebaya-dalam-kelompok.html. Diakses 20 Januari 2015 